any printed matter at all. This is, therefore, essentially a picture book with most of the illustrations being old snapshots of people, usually standing rifle in hand over a dead beast, or of decaying large mammals. One 'chapter' consists only of pictures, mostly aerial shots of decomposing elephants which only the cognoscenti will recognize as victims of the 1970/71 drought in Tsavo. Few of the photographs are captioned and some are grossly misleading; e.g. the apparent elephants' graveyard is presumably a bone dump behind a field laboratory. So confused is the book that one assumes it must contain a 'message', but it is difficult to fathom what that message is. At one level, it seems to be no more than a lament for the past, and there is also the implication that the invading white man is to blame for the changes that have taken place. But does the author really think that Africa could have remained forever isolated from the outside world, or does he want African reservations, similar to those for Indians in his native America, where 'the harmonies and balances of the early days' can be maintained? It is only in the Epilogue, written by R. M. Laws, that the real message comes through, viz. that if we want to conserve the game in national parks, it may be necessary to control elephant populations by culling. Failure to manage elephants may lead to habitat deterioration as in Tsavo and to the suffering portrayed in Chapter 6 of this book, but Africa is more than Tsavo, or than Kenya for that matter, and there is still time in which to save her wildlife. The real threat is the burgeoning human population, and unless we can get that under control very soon it will indeed be the end of the game for us all.

S.K. EI.TRINGHAM

\title{
Lifeboats to Ararat, by Sheldon Campbell. Weidenfeld \& Nicolson, £6.50.
}

From personal knowledge of the author, and the foreword by Gerald Durrell, I had hoped that this book would fill the need for a thoughtful, well-documented and well-argued commentary on the present, and likely future, role of zoos in the conservation of species. Sadly, however, either the author himself, or more probably his publishers, have unwittingly reflected one of the greatest problems facing a conscientious modern zoo director, which is the need for popular appeal. Consequently large sections of the book are filled with anecdotes gleaned by the author from various sources, mostly American, and of the type that appeal to the general reader interested in animals.

The stories reflect animal idiosyncrasies, visitor eccentricities, some of the problems caused by well-intended conservation legislation, particularly as applied in the US, and the physical dangers inherent in zoo work, which I have always found to be an unfailing source of interest to lay people. To sell a book to the general public, therefore, it is presumably necessary to give them what they want; this the author has done very well. $\mathrm{He}$ has both wit and resourcefulness as when, for instance, in a reference to motherhood being at least partially a learned art amongst the higher mammals, he coins the phrase "evolution had created a market for Dr Spock'.

Some excellent points are made. He refers to a constant dilemma of zoo decision. makers, the conflict between the public's desire to see young animals being hand-reared in nurseries and thereby being available for use with the media, or reared by their mothers. I know from personal experience that publicity for a zoo is most easily achieved by having tame animals available to take into a television studio or be posed with a celebrity. I also know that this is seldom in the interest of the animal concerned and never in the interest of the species. I would be surprised if today any reputable zoo in fact chose to have handreared animals in its collection.

I cannot be happy either with the emphasis on market value of animals, as hopefully fewer and fewer zoos are now concerned with this. High money values will inevitably in most cases be counter-productive as far as species survival is concerned. The 'open market' is something which should no longer exist in the context of, for instance, gorillas, where this phrase occurs. 